\title{
RAG1 Gene
}

National Cancer Institute

\section{Source}

National Cancer Institute. RAG1 Gene. NCI Thesaurus. Code C80068.

This gene is involved in immunoglobulin diversity. 